\title{
The Twilight of the Berle and Means Corporation
}

\author{
Gerald F. Davis ${ }^{\dagger}$
}

During the five decades after Berle and Means published The Modern Corporation and Private Property in 1932, ${ }^{1}$ their analysis became the dominant understanding of the American corporation. Social scientists, policymakers, and the broader interested public knew about the separation of ownership and control, the potentially fraught relations between shareholders and managers, and the image of the corporation as a social institution. Berle and Means's view of an economy dominated by a handful of ever-larger corporations run by an unaccountable managerial class inspired scholarship from sociologists (who were convinced they were right) to financial economists (who wanted to prove them wrong) to lawyers (who contemplated the rights and obligations implied by this system).

A decade into the twenty-first century, however, the public corporation may have reached its twilight in the United States. The "shareholder value" movement of the past generation has succeeded in turning managers into faithful servants of share price maximization, even when this comes at the expense of other considerations. But the shareholder value movement also brought with it a series of changes that have undone many core features of the Berle and Means corporation. Corporate ownership is no longer dispersed; ${ }^{2}$ the concentration of assets and employment have been in decline for three decades, ${ }^{3}$ and today's largest corporations bear little resemblance to the companies analyzed by Berle and

$\dagger$ Wilbur K. Pierpont Professor of Management, Ross School of Business, and Professor of Sociology, University of Michigan.

1. Adolf A. Berle, Jr., \& Gardiner C. Means, The Modern Corporation and Private PROPERTY (1932).

2. Gerald F. Davis, A New Finance Capitalism? Mutual Funds and Ownership ReConcentration in the United States, 5 EuR. MGMT. REV. 11, 12 (2008).

3. Lawrence J. White, What's Been Happening to Aggregate Concentration in the United States? (And Should We Care?) (N.Y. Univ., Working Paper No. EC-02-03, 2001), available at http://papers.ssrn.com/sol3/papers.cfm?abstract_id=1292649. 
Means. ${ }^{4}$ Moreover, there are far fewer of them than there used to be: the United States had half as many publicly traded domestic corporations in 2009 as it did in 1997..$^{5}$ In another generation, the Berle and Means corporation may be just a memory, overtaken by new forms of organization and financing.

In this Article, I draw on a series of recent studies and empirical observations to describe the rise and fall of the Berle and Means corporation. Part I describes the four major features of the American corporate system as presented by Berle and Means and how this view came to dominate thinking about the corporation among social scientists. Part II lays out the theoretical challenges to this view that underlay the shareholder value movement and the changes wrought by the 1980s bust-up takeover wave. In Part III, I describe how each of the four features of the Berle and Means corporation has been undone over the past two decades, concluding that the corporation no longer fits its description as a social institution. It has instead come to resemble the "nexus of contracts" proposed by Berle and Means's critics in economics. Part IV closes with speculation about the possibilities for fruitful collaboration between lawyers and social scientists as we contemplate what comes next.

\section{THE CORPORATION AS A SOCIAL INSTITUTION 1932-1982}

Berle and Means opened The Modern Corporation and Private Property with an analysis of the public corporation that proved to be remarkably enduring. In the first three decades of the twentieth century, the United States had evolved a new form of economic order analogous to the feudal system that preceded competitive capitalism. The key to this new economic order was the modern corporation, an encompassing social form that rivaled the state in its far-reaching powers. According to Berle and Means:

The economic power in the hands of the few persons who control a giant corporation is a tremendous force which can harm or benefit a multitude of individuals, affect whole districts, shift the currents of trade, bring ruin to one community and prosperity to another. The organizations which they control have passed far beyond the realm of private enterprise - they have become more nearly social institutions. $^{6}$

4. The petroleum sector is one notable exception in that the dominant oil companies analyzed by Berle and Means - primarily the many "progeny" of the original Standard Oil Companymaintain their dominance today. See BERLE \& MEANS, supra note 1, at 4.

5. THE WORLD BANK, WORLD DEVELOPMENT INDICATORS (2010), available at http://data. worldbank.org/data-catalog/world-development-indicators/wdi-2010.

6. BERLE \& MEANS, supra note 1 , at 46. 
Four premises stand out from the analysis that opens The Modern Corporation. First, "[e]conomic power, in terms of control over physical assets, is apparently responding to a centripetal force, tending more and more to concentrate in the hands of a few corporate managements." third chapter of The Modern Corporation documents this centripetal tendency. Through mergers and organic growth, assets and employment had become increasingly concentrated among a relative handful of corporations. By 1930, the 200 largest corporations controlled 49.2\% of corporate wealth, ${ }^{8}$ and if the trends observed by Berle and Means had continued, they would have controlled it all by $1959 .^{9}$

Second, "beneficial ownership is centrifugal, tending to divide and subdivide, to split into ever smaller units and to pass freely from hand to hand." 10 During the decade after the end of the First World War, retail investment in stocks and bonds grew dramatically, and the number of shareholders doubled from 2.4 million in 1924 to 5 million in 1927, doubling again to 10 million in $1930 .{ }^{11}$ Chapter 4 of the book describes the broad dispersion of stock ownership among the public, while Chapter 5 shows the consequences for the corporation: $44 \%$ of the largest 200 corporations were under effective management control, with no single entity holding more than $5 \%$ of the voting stock. ${ }^{12}$

Third, large corporations typically make physical products, transport them, or provide infrastructure. The 200 large corporations analyzed by Berle and Means included 106 industrials, 52 utilities, and 42 railroads, nearly all entailing large-scale physical operations. "The factory system, the basis of the industrial revolution, brought an increasingly large number of workers directly under a single management." ${ }^{\text {"14 }}$ It was the grand scale of contemporary methods of production that required issuing shares to the public in the first place, because few families had the wherewithal to fund them. When Ford's famous Rouge Plant began turning out Model A cars in 1927, for instance, it employed 75,000 workers and grew from there to well over $100,000 .{ }^{15}$ The large size of the modern

7. Id. at 9.

8. Id. at 32 .

9. Id. at $40-41$.

10. Id. at 9 .

11. EDWin Burk Cox, TRENDS In THE Distribution OF StOCK OWNERShiP 33 (1963).

12. BERLE \& MEANS, supra note 1, at 93-94.

13. $I d$. at $20-27$.

14. Id. at 3 .

15. Vivian Baulch \& Patricia Zacharias, The Rouge Plant-The Art of Industry, DETROIT NeWs (July 11, 1997), http://apps.detnews.com/apps/history/index.php?id=189. Ford, however, was the exception to the rule of public ownership, as the company was privately held at the time Berle and Means wrote, and remained so until its initial public offering in 1956. 
corporation matched the large scale of tangible activities that it performed.

Fourth, corporations are long-lasting relative to the individuals whose destinies they control. "Bankruptcy" and "liquidation" do not appear in the index of Berle and Means's 1932 edition and play little conceptual role in the text, in spite of the fact that it was written during the Great Depression. Rather, like states, corporations were expected to be enduring features of the societal landscape. Berle and Means opined that if trends continued, corporations might come to rival states as "the dominant institution of the modern world." 16 They were "economic empires" that were in "the hands of a new form of absolutism, relegating 'owners' to the position of those who supply the means whereby the new princes may exercise their power." 17 This analogy with feudalism was a recurring motif in the book.

The book closes with a speculative vision of how the nascent corporate system might evolve to take on features of a new and benevolent feudalism:

Should the corporate leaders, for example, set forth a program comprising fair wages, security to employees, reasonable service to their public, and stabilization of business, all of which would divert a portion of the profits from the owners of passive property, and should the community generally accept such a scheme as a logical and human solution of industrial difficulties, the interests of passive property owners would have to give way. Courts would almost of necessity be forced to recognize the result, justifying it by whatever of the many legal theories they might choose. ${ }^{18}$

In short, the "paramount interests of the community" would trump those of both shareholders and managers. ${ }^{19}$

By the 1950s, Berle and Means's vision of a society dominated by management-controlled large corporations was ensconced in social science and in the popular imagination. Management theorist Peter Drucker, who had studied General Motors under Alfred P. Sloan, wrote in Harper's Magazine that in the contemporary American economy, "[t]he representative, the decisive, industrial unit is the large, mass-

16. BERLE \& MEANS, supra note 1 , at 356.

17. Id. at 124 .

18. Id. at 356.

19. Id. Compare Adolf A. Berle, Jr., Corporate Powers as Powers in Trust, 44 HARV. L. REV. 1049 , 1049 (1931) (arguing that "all powers granted to a corporation or to the management of a corporation ... are necessarily ... exercisable only for the ratable benefit of all the shareholders as their interest appears"), with Adolf A. Berle, JR., The 20TH Century CAPITAlist Revolution 169 (1954) (conceding twenty years later that the shareholder primacy view had, in practice, been decisively defeated by the community-centered view). 
production plant, managed by professionals without ownership-stake, employing thousands of people, and organized on entirely different technological, social, and economic principles" than traditional businesses controlled by their owners. He described the large corporation as a synecdoche for American society: "The big enterprise is the true symbol of our social order.... In the industrial enterprise the structure which actually underlies all our society can be seen ...."20 The ways of the managerialist mass-production corporation had become the operating system of American society, from the farm to the school to the government itself.

Economist Carl Kaysen claimed that the professional managers who ran America's major corporations had evolved into a caste of benevolent elites who took seriously the corporation's responsibility to the paramount interests of the community:

No longer the agent of proprietorship seeking to maximize return on investment, management sees itself as responsible to stockholders, employees, customers, the general public, and, perhaps most important, the firm itself as an institution. ... [Moreover, its] responsibilities to the general public are widespread: leadership in local charitable enterprises, concern with factory architecture and landscaping, provision of support for higher education, and even research in pure science, to name a few. ${ }^{21}$

Ralf Dahrendorf, a sociologist, argued that the separation of ownership and control identified by Berle and Means marked a sharp break with prior forms of economic organization, and stated that there was "an astonishing degree of consensus among sociologists on the implications of joint-stock companies for the structure of industrial enterprises, and for the wider structure of society." 22 America was no longer, strictly speaking, a capitalist economy, but rather a new kind of industrial economy, and those in charge of business followed organizational imperatives other than profit maximization. Professional managers were distinctly different from traditional business owners in their outlook and motivation: "Among classical capitalists, the 'organization man' is an unthinkable absurdity. ... Never has the imputation of a profit motive been further from the real motives of men than it is for modern bureaucratic managers." 23 And C. Wright Mills, another sociologist, while disagreeing

20. Peter F. Drucker, The New Society: I. Revolution by Mass Production, HARPER's MAG., Sept. 1949, at 29.

21. Carl Kaysen, The Social Significance of the Modern Corporation, 47 Am. Econ. REv. 311, 313 (1957).

22. RALF DAHRENDORF, CLASS AND ClASS CONFLICT IN INDUSTRIAL SOCIETY 42 (1959).

23. Id. at 46 . 
with Kaysen's sanguine view of public-spirited corporate elites, nonetheless took for granted the view that management had been largely freed from the demands of finance: "Not 'Wall Street financiers' or bankers, but large owners and executives in their self-financing corporations hold the keys of economic power." 24

For a generation after the writings of these mid-century theorists, corporations continued to grow larger and more encompassing. The diversifying merger movement of the 1960s added a new form of megacorporation to the group identified by Berle and Means. Conglomerates such as ITT, LTV, Gulf \& Western, and Litton Industries grew vast through strings of acquisitions across dozens of industries, joining traditional blue chips like AT\&T and General Motors. ITT grew from 132,000 employees in 1960 to 392,000 in 1970, adding Sheraton Hotels, Hartford Insurance, Continental Baking, Avis Rent-a-Car, and dozens of other businesses to its portfolio. ${ }^{25}$ During the same period, GM added 100,000 workers and AT\&T added almost 200,000. ${ }^{26}$ Moreover, this growth in the size of the largest corporations corresponded to a period of great economic prosperity and declining income inequality. The Gini index of income inequality dropped to its lowest level on record in the United States in 1968, just as corporate employment concentration reached its apex. ${ }^{27}$

Berle and Means's prophecy about the ever-increasing concentration of corporate control seemed to have come true. Policymakers responded by drafting the large corporation into service as a tool for addressing social ills on a grand scale. If a few dozen giant corporations controlled the bulk of the economy, then efforts at social and economic reform could get the most leverage by targeting these firms. Thus, during the years of the Nixon Administration, corporations became a central mechanism to realize policy goals around environmental protection (the creation of the Environmental Protection Agency in 1970), workplace safety (the passage of the Occupational Safety and Health Act of 1970), product safety (the passage of the Consumer Product Safety Act of 1972), and equitable employment practices (the passage of the Equal Employment Opportunity Act of 1972, giving the EEOC litigation authority). Corporate concentration may have been bad for competition, but it certainly made the job of would-be social engineers a lot easier.

24. C. Wright Mills, The POWER Elite 125 (1956).

25. Gerald F. Davis \& J. Adam Cobb, Corporations and Economic Inequality Around the World: The Paradox of Hierarchy, 30 RES. IN ORG. BEHAV. 35, 35-53 (2010).

26. Id.

27. Id. at 47 . 


\section{THE DOMINANCE OF SHAREHOLDER VALUE 1982-2001}

But as the corporation-as-institution was reaching its apex in reality, it was being undermined in theory. In 1965, Henry Manne argued that those who accepted the premise of managerial hegemony, following Berle and Means, may have been too hasty. There was a limit to how much corporate managers could abuse their investors on behalf of themselves or other constituencies. That limit was enforced by a previously unrecognized "market for corporate control": poorly managed companies suffered low valuations on the stock market, attracting entrepreneurs who could buy control of the company on the market, fire the laggards in charge, and renovate the firm for a quick profit. Only an outmoded approach to antitrust prevented this from happening on a large scale. ${ }^{28}$

Others decried the view of the corporation as a social institution as delusional. Corporations had neither power nor obligations with respect to their members, who were all voluntary participants. Armen Alchian and Harold Demsetz, for example, asked:

What then is the content of the presumed power to manage and assign workers to various tasks? Exactly the same as one little consumer's power to manage and assign his grocer to various tasks. ... I have no contract to continue to purchase from the grocer and neither the employer nor the employee is bound by any contractual obligations to continue their relationship. ${ }^{29}$

Michael C. Jensen and William H. Meckling combined these ideas into a comprehensive critique of the Berle and Means view of the corporation. First, it simply didn't make sense that investors would put their savings into shares of companies run by unaccountable managers. There must be forces to compel management's attention to share price, or else their company would fail or be taken over as investors shunned their securities and the company's share price declined. Financial markets, far from being irrelevant, provided a minute-by-minute report card on managerial quality, and there were a host of mechanisms that gave management incentives to care what the financial markets thought. Second, the view of the corporation as a social institution that might rival the state was simply wrong: the corporation was nothing more than a "nexus of contracts" among voluntary, individual participants. As Jensen and Meckling explained: (1965).

28. Henry G. Manne, Mergers and the Market for Corporate Control, 73 J. POLIT. ECON. 110

29. Armen A. Alchian \& Harold Demsetz, Production, Information Costs, and Economic Organization, 62 AM. ECON. REV. 777, 777 (1972). 
$[\mathrm{M}]$ ost organizations are simply legal fictions which serve as a nexus for a set of contracting relationships among individuals.... Viewed this way, it makes little or no sense to try to distinguish those things that are "inside" the firm (or any other organization) from those things that are "outside" of it. There is in a very real sense only a multitude of complex relationships (i.e., contracts) between the legal fiction (the firm) and the owners of labor, material and capital inputs and the consumers of output. ${ }^{30}$

When it came to the corporation, there was no "there" there. This view was provocative, contrary to conventional wisdom, and, ultimately, highly influential.

During the Reagan Administration, the theoretical dream of Manne and his heirs came true, as financial markets became the North Star guiding corporate decision-making. Three policy changes around 1982 were particularly consequential for precipitating the "shareholder value" movement. First, the Department of Justice released a set of merger guidelines that substantially eased limitations on within-industry mergers. Second, the Supreme Court's Edgar v. MITE decision ${ }^{31}$ struck down a set of state laws limiting hostile takeovers of domestic corporations under the Commerce Clause. Third, based on an IRS ruling in 1981, corporations began to offer 401(k) plans to their employees as a supplement and, eventually, a replacement for traditional defined-benefit pension plans.

The first two of these changes helped unleash a wave of hostile takeovers aimed largely at the conglomerates built up during the 1960s and 1970s. Diversified firms were systematically undervalued on the stock market relative to focused firms in the same industries, a regularity that was dubbed the "conglomerate discount." The loss of state-level takeover protection made firms vulnerable to outside tender offers, and the revised merger guidelines meant that the parts of conglomerates could more readily be sold to buyers in related industries. In combination with the new availability of large-scale bridge financing through "junk bonds" and other means, this created the perfect context for raiders to buy conglomerates, bust them up, and sell the parts for a profit, which is precisely what happened. During the 1980 s, $29 \%$ of the Fortune 500 largest industrials received tender offers, and one in three were ultimately acquired or merged. ${ }^{32}$ This was the largest industrial reorganization in the United

30. Michael C. Jensen \& William H. Meckling, Theory of the Firm: Managerial Behavior, Agency Costs and Ownership Structure, 3 J. Fin. ECON. 305, 309-10 (1976) (emphasis added).

31. Edgar v. MITE Corp., 457 U.S. 624 (1982).

32. Gerald F. Davis \& Suzanne K. Stout, Organization Theory and the Market for Corporate Control: A Dynamic Analysis of the Characteristics of Large Takeover Targets, 1980-1990, 37 ADMIN. SCI. Q. 605, 605 (1992). 
States since the merger wave at the turn of the twentieth century, which had created the large corporation as we know it. Of the firms that remained, dozens voluntarily restructured through spin-offs and other means, and broad, unrelated acquisitions nearly disappeared as a growth tactic. ${ }^{33}$ After a decade of mergers, the largest firms actually ended up smaller than they were at the start, reducing aggregate corporate concentration in the economy. ${ }^{34}$ As we will see below, the trend in disaggregation continued throughout the 1990s and 2000s as innovative new means for outsourcing arose in nearly every sector.

The third change - the advent of the 401(k) - had complementary effects in reinforcing the power of financial markets relative to corporations. First, it helped create a broad new constituency for "shareholder value," as an increasingly large part of the population became invested in the stock market. The proportion of households with money invested in the market increased from just over $20 \%$ in 1983 to more than $50 \%$ by $2001 .^{35}$ It also channeled the vast new pools of capital created through employee savings through mutual funds, which grew from $\$ 135$ billion in assets under management in 1980 to $\$ 7$ trillion in $2000 .{ }^{36}$ Broad popular participation in the stock market, coupled with a relatively concentrated set of institutional investors, thus created a strong counterweight to "imperial" corporate managers.

By the late 1990s, there was wide agreement among corporate managers, directors, shareholders, and many scholars that the corporation existed to create shareholder value. ${ }^{37}$ This triumph of the shareholders was not inevitable. Michael Jensen, perhaps the strongest academic voice for shareholder primacy, proclaimed the "eclipse of the public corporation" in a 1989 article in Harvard Business Review. ${ }^{38} \mathrm{He}$ argued that the fundamental conflict between those who own the public corporation and those who manage it could not ultimately be resolved, that professional managers were deviously clever in finding ways to avoid the discipline of outside markets (by adopting poison pills, for example), and that alternative forms of business organization (such as leveraged buyout part-

33. Gerald F. Davis et al., The Decline and Fall of the Conglomerate Firm in the 1980s: The Deinstitutionalization of an Organizational Form, 59 AM. Soc. REV. 547, 547 (1995).

34. See White, supra note 3.

35. Brian K. Bucks et al., Recent Changes in U.S. Family Finances: Evidence From the 2001 and 2004 Survey of Consumer Finances, FED. RES. BULL., at A1 (2006), available at http://www.federalreserve.gov/pubs/bulletin/2006/financesurvey.pdf.

36. 2010 INVESTMENT COMPANY FACT BOOK (2010), available at http://www.icifactbook.org/.

37. Henry Hansmann \& Reinier Kraakman, The End of History for Corporate Law, 89 GEO. L.J. 439, 441 (2001).

38. Michael C. Jensen, Eclipse of the Public Corporation, HARV. Bus. ReV., Sept.-Oct. 1989, available at $\mathrm{http}: / / \mathrm{hbr}$.org/1989/09/eclipse-of-the-public-corporation/ar/1. 
nerships) offered an attractive solution to the problems created by the separation of ownership and control. ${ }^{39}$

During the subsequent decade, however, upwards of 3,000 corporations went public in the United States, in industries such as biotechnology, computers, energy, and business services. By 1997, the United States had 8,851 publicly traded corporations - an increase of more than onethird compared to 1990, and the highest level on record. ${ }^{40}$ Moreover, the managers of these corporations evidently had no illusions about the purposes of their firms: they existed to create shareholder value, not to cater to various alleged "stakeholders." Consider the mission statements of two Fortune 100 corporations in the late 1990s. According to the CocaCola Company, "We exist to create value for our share owners on a longterm basis by building a business that enhances The Coca-Cola Company's trademarks." 41 Sara Lee Corporation took a similar view: "[Our] mission is to build leadership brands in consumer packaged goods markets around the world. Our primary purpose is to create long-term stockholder value." ${ }^{42}$ Any broader conception of corporate purpose seemed to have been vanquished.

\section{THE TWILIGHT OF THE PUBLIC CORPORATION IN THE EARLY TWENTY-FIRST CENTURY}

A decade into the twenty-first century, the core premises of the Berle and Means corporation have given way to a rather different situation, due in large part to the success of the shareholder value movement. I will consider each premise in turn.

The first premise, that corporate ownership is centrifugal, has been undermined by the unprecedented growth of a handful of mutual funds in the United States. Due to the vast increase in retail and 401(k) investment, mutual funds' net assets were almost 100 times larger in 2007 (\$12 trillion) than they were in 1980 ( $\$ 135$ billion), and the number of shareholder accounts increased from 12 million to over 290 million. ${ }^{43}$ Moreover, the bulk of this growth went to a handful of well-known mutual funds; the share of assets held by the top five fund complexes in 2009, at $39 \%$, was about the same as it had been in $1985 .{ }^{44}$ Thus, name-brand fund families - in particular Fidelity, Vanguard, and the American

39. Id.

40. WORLD BANK, supra note 5.

41. Gerald F. Davis, Managed by the Markets: How FinAnCE Re-Shaped America 86 (2009).

42. Id.

43. 2010 INVESTMENT COMPANY FACT BOOK, supra note 36.

44. Id. at fig.2.2. 
Funds-grew to become the largest shareholders in corporate America during the 1980s and 1990s. For actively managed funds such as Fidelity and the American Funds, this meant that their holdings in particular portfolio companies were often highly concentrated. By the late 1990s, Fidelity was the largest single shareholder of one in ten United States corporations, often holding blocks of $10 \%-15 \%$ or more, even among competitors in the same industry. ${ }^{45}$ It appears that corporate ownership in the United States has become more concentrated than at any point since the heyday of J.P. Morgan in the early twentieth century. ${ }^{46}$ Ironically, this renewed concentration is due to the growth of retail investment, which had led to the dispersion of corporate ownership in the 1920s.

The second premise is that corporate control is centripetal, and that corporations tend to increase the assets and employees under their control, leading to increasing concentration over time. As previously discussed, corporate concentration began to decline during the 1980s takeover wave, and this trend continued through the 1990s and 2000s. In 1960, the twenty-five largest firms in the United States employed the equivalent of $6.1 \%$ of the private labor force; in 1970 , it had risen to $9.3 \%$; in 1980 , it was $7.3 \%$; in 1990 , it had dropped to $5.8 \%$; and by 2000 , it declined to $4.0 \%$ - less than half of the equivalent figure thirty years prior. ${ }^{47}$

Standing behind these declines in corporate concentration are substantial changes in the organization of production in the United States economy. These changes might be summarized as "Nikefication." Nike is well-known for its modular model of producing shoes and athletic gear: while the company engages in the design and marketing of its goods, manufacturing is almost entirely done by overseas contractors, primarily in East Asia. The theory behind this model is that high valueadded activities (the knowledge-based work of design and marketing) should be done by the company that owns the brand, while lower valueadded activities, such as assembly and supply chain management, can be contracted out. Although the Nike model has a long history in apparel, thanks to Wall Street pressures and the availability of an outsourcing sector, the model spread widely throughout the electronics industry and is now standard practice in industries from consumer packaged goods to pharmaceuticals. The articulation of a large sector of generic manufac-

45. Davis, supra note 2, at 12 (1914)

46. $C f$. Louis D. Brandeis, Other People's Money: And How the Bankers Use IT

47. Davis \& Cobb, supra note 25; see also White, supra note 3 (documenting similar declines in asset concentration). 
turers (known in electronics as "board stuffers"), often operating overseas, allows even the smallest company to produce on a large scale.

One result of this movement is that a company can be large in revenues and market capitalization while remaining quite small in employment and assets. According to its $10-\mathrm{K}$ for 2010 , Nike is "the largest seller of athletic footwear and athletic apparel in the world" with over \$19 billion in revenues, a market capitalization of $\$ 42$ billion, and 700 retail outlets. Yet it employs only 34,400 people globally. ${ }^{48}$

Although the prevalence of Nikefication is hard to quantify-the model does not leave obvious traces in public records - a handful of examples will illustrate its implications. The company with the largest U.S. market share for LCD televisions in 2010 was not Sony or Samsung, but Vizio, based in Irvine, California. Vizio's CEO built the firm earlier in the decade by recognizing that the parts and know-how to build televisions were readily available on the market-like the components of a $\mathrm{PC}$ - and that the critical element was a distribution channel, which he duly negotiated with Costco and other big-box stores. The televisions are assembled by a Taiwanese firm with an ownership stake in privately held Vizio, and they generally retail at a much lower cost than those produced by Vizio's name-brand competitors. By 2010, the company had several billion dollars in revenues, plans to roll out a tablet computer and a smart phone, ${ }^{49}$ and fewer than 200 employees. ${ }^{50}$

In pet food, over 100 brands, from Science Diet to the Walmart store brand, are manufactured by Menu Foods of Ontario in a single factory, a fact that was revealed in 2007 when much of the nation's pet chow turned out to be tainted with melamine from its Chinese suppliers. ${ }^{51}$ In pharmaceuticals, the widely used blood thinner heparin, sold by Baxter International, was recalled in 2008 when it was attributed with the deaths of at least eighty-one patients and injuries of several hundred more. It had been produced under contract in a Chinese factory that relied on mom-and-pop suppliers for its critical ingredient, pig intestines. ${ }^{52}$ And in corporate law, companies that choose to incorporate in Liberia (such as Miami-based Royal Caribbean Cruises and several other shipping companies) find that Liberian incorporation is handled by an off-

48. Nike Inc., Annual Report (Form 10-K) (July 20, 2010).

49. Christopher Lawton et al., U.S. Upstart Takes On TV Giants in Price War, Wall ST. J., Apr. 15, 2008, at A1.

50. About Vizio, VizIO, INC., http://www.vizio.com/about/ (last visited Apr. 9, 2011).

51. Ellen Byron, 101 Brand Names, 1 Manufacturer, WALL ST. J., May 9, 2007, at B1.

52. Gardiner Harris, U.S. Identifies Tainted Heparin in 11 Countries, N.Y. TIMES, Apr. 22, 2008, http://www.nytimes.com/2008/04/22/health/policy/22fda.html?pagewanted=1; House Panel Criticizes F.D.A. Role in Drug Cases, N.Y. TIMES, Apr. 23, 2008, http://www.nytimes.com/ 2008/04/23/health/policy/23heparin.html. 
shore vendor located in Vienna, Virginia, near Dulles Airport. ${ }^{53}$ The American corporation, in short, increasingly resembles the nexus-ofcontracts described by the financial economists.

Berle and Means's third premise is that the typical corporation makes or transports tangible products. But the previous examples hint that this is no longer the case, and more systematic data provide further evidence against it. During the first decade of the twenty-first century, manufacturing employment in the United States declined by one-third, and by March 2009, more Americans were unemployed than were employed in manufacturing. ${ }^{54}$ This shift is reflected in the character of the largest employers. In 1960, the five largest private employers in the United States consisted of AT\&T and four vertically integrated manufacturers - GM, Ford, GE, and U.S. Steel. In 1980, U.S. Steel had been replaced in the top five by Sears. By 2010, however, nine of the twelve largest employers were retailers, and none were manufacturers. Indeed, Walmart alone employed as many Americans as the twenty largest manufacturers combined. ${ }^{55}$

Whereas large manufacturers characteristically have relatively low turnover, long employee tenures (eight years on average in auto manufacturing), and high wages (over $\$ 27$ per hour for auto workers), retailers have high turnover (an estimated 40\% annually at Walmart), low tenure (three years on average), and low wages ( $\$ 9.33$ per hour in "general merchandise retailing"). ${ }^{56}$ Retail also has characteristically different forms of work organization. Where Ford's Rouge Plant employed over 100,000 people at its peak, a typical Walmart Supercenter employs roughly 350 people in a highly modular format. Thus, with Nikefication has come a substantial shift in the nature of the largest corporate employers; the factory system that precipitated the modern large corporation had become marginal to employment in the United States.

The final premise is that corporations are relatively long-lived. This premise was not explicit, but the image of corporations as analogous to feudal manors makes little sense in a world of high corporate turnover.

53. See DAVIS, supra note 41 , at ch. 5 (stating the rise of contractors for U.S. government work, such as armed protection of diplomats in Iraq, is well-documented elsewhere); Contact Us, LIBERIAN REGISTRY, http://liscr.com/liscr/ContactUs/tabid/160/Default.aspx (last visited Apr. 9, 2011).

54. Bureau of Labor Statistics, Data Retrieval: Employment, Hours and EARNingS (CES), http://www.bls.gov/webapps/legacy/cesbtab1.htm (last visited Feb. 5, 2010).

55. See DAVIS, supra note 41 , at ch. 3.

56. Bureau of Labor Statistics, Labor Force Statistics From CURRENT Population SURVEY, http://bls.gov/cps/earnings.htm (last visited Apr. 1, 2011); U.S. BUREAU OF CENSUS, Current Population Survey, January 2004: Displaced Workers, Employee Tenure, and OCCUPATIONAL MOBiLity SUPPLEMENT File (2004), available at http://www.census.gov/apsd/ techdoc/cps/cpsjan04.pdf. 
Berle and Means's prediction that a handful of identifiable corporations would come to dominate the American economy was not a bad guess. The half-century after they wrote The Modern Corporation was distinguished by remarkable stability at the core of the corporate economy compared with what had come before. For instance, of the thirty firms included in the Dow Jones Industrial Index in 1930, sixteen of them were still there in 1987, almost six decades later. ${ }^{57}$ Yet by 2009 , all but threeChevron, Exxon, and GE-were gone due to bankruptcies, mergers, or radical reorganizations, such as Woolworth's rebranding as Foot Locker or Westinghouse's transformation into CBS. Recent exits from the index include GM, AIG, and Citigroup, all of which had inadvertently become government-supported enterprises due to the financial crisis.

Thanks to Nikefication, it is sometimes difficult to distinguish which corporations are still with us and which have moved on to their great reward. Circuit City, for instance, was a large national retailer with over 34,000 employees and stores across the United States when it fell into liquidation in early 2009 and its employees were all fired. ${ }^{58}$ Yet the familiar logo and brand name live on at www.CircuitCity.com, a website now operated by Systemax, a Long Island-based direct marketer that purchased the Circuit City brand and domain name for $\$ 14$ million at a bankruptcy auction. Similar fates befell other retailers, such as Linens 'n Things and CompUSA, indicating that retail may be no safe haven for stable employment in an era of automated web-based order fulfillment.

Perhaps the most compelling challenge to the view of the United States as a corporate-centered society is the sheer decline in the number of public corporations. As Figure 1 shows, the number of public corporations in the United States in 2009 was half what it had been in 1997. This number had declined by over $21 \%$ just between 2008 and 2009. The "eclipse of the public corporation" prophesied by Michael Jensen in 1989 finally seems to have come true, although perhaps not for the reasons he predicted.

57. Dow Jones Indexes, Dow Jones Industrial AVERAge Historical COMPONENTS, http://www.djindexes.com/mdsidx/downloads/brochure_info/Dow_Jones_Industrial_Average_Histo rical_Components.pdf (last visited Apr. 9, 2011).

58. Circuit City to Liquidate Remaining U.S. Stores, MSNBC (Jan. 16, 2009), http://www.msnbc.msn.com/id/28691963/ns/business-us_business/. 
Figure 1: Number of listed U.S. domestic corporations, 1988-2009 $9^{59}$

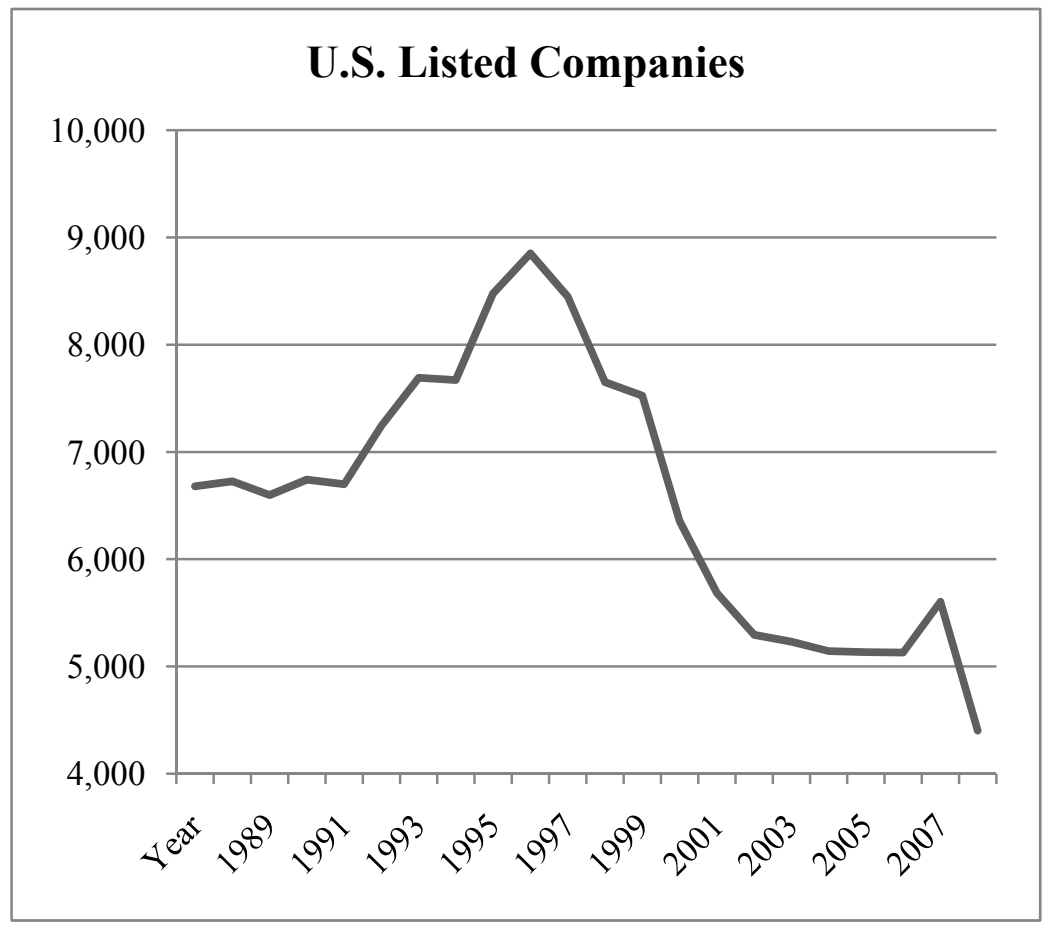

Cross-national comparisons suggest that this is not a global consequence of the economic downturn. India actually surpassed the United States in its number of public corporations in 2009, and China also maintained a large set of public corporations. Germany, on the other hand, was down to roughly 600 public corporations - fewer than Pakistandespite its relatively healthy economy. ${ }^{60}$

In just over a generation, the shareholder value movement had laid to rest the familiar corporation described by Berle and Means. In recent years, corporations have grown less numerous, less integrated, less concentrated, more ephemeral, and more constrained by their shareholders.

One consequence of corporate disaggregation is that corporations cannot fulfill public policy goals as effectively as they could during the Nixon Administration, when a mere twenty-five firms employed nearly $10 \%$ of the workforce. Consider the top economic priority of the Obama Administration, which is to create more jobs and reduce unemployment. The widely shared folk wisdom is that the path to greater employment

59. WORLD BANK, supra note 5.

60. Id. 
runs through entrepreneurship. The day after Obama's State of the Union address in 2010, the Wall Street Journal published an op-ed by the publisher of Forbes that stated the case plainly, drawing on the experience of Steve Jobs and Apple, which had just released its iPad. "Mr. Obama and his advisors need to grasp this essential fact: Entrepreneurs are not just a cute little subsector of the American economy. They are the whole game. They will give us tomorrow's Apples and the multiplier effect of small businesses and exciting new jobs that go with them." 61

Yet the very next issue included an article entitled Analysts expect iPad to give lift to Asian suppliers, ${ }^{62}$ which contained this statement: "Like many technology brands, Apple doesn't actually manufacture most of its products. It hires manufacturing specialists - mainly Taiwanese companies that have extensive operations in China - to assemble its gadgets based on Apple's designs." ${ }^{63}$ The article specifically mentions Hon Hai Precision Industry of Taiwan as the assembler of choice. ${ }^{64} \mathrm{~A}$ few weeks later, Hon Hai lost its previous anonymity when a string of suicides by its workers in Shenzen, China, revealed just how exciting the jobs created by Apple actually were. ${ }^{65}$

With just over 34,000 employees around the world, Apple creates relatively few jobs in the United States with its innovative products because it follows the Nike model of production. And Apple is not alone in this regard; the brain trust of corporate innovation in the United States has created a great deal of shareholder value, but not that many jobs. Collectively, Apple (with 34,300 employees), Google (19,835), Intel $(79,800)$, Amazon.com $(24,300)$, Cisco $(65,550)$, and Microsoft $(93,000)$ employed only 316,785 workers, of which 215,485 were employed in the United States in 2010. For comparison purposes, grocery chain Kroger had 334,000 workers in the United States. Somewhat more pointedly, the United States lost 598,000 net jobs in January 2009 alone- the equivalent of 17.43 Apples. ${ }^{66}$

61. Rich Karlgaard, Op-Ed., Apple to the Rescue?, WALL ST. J., Jan. 28, 2010, http://online.wsj.com/article/SB10001424052748704094304575029350404353026.html.

62. Aaron Back et al., Analysts Expect iPad to Give Lift to Asian Suppliers, Wall St. J., Jan. 29, 2010, http://online.wsj.com/article/SB10001424052748704878904575030633950504718.html.

63. Id.

64. Id.

65. David Barboza, String of Suicides Continues at Electronics Supplier in China, N.Y. TIMES, May 25, 2010, at B10.

66. Amazon.com Inc., Annual Report (Form 10-K) (Jan. 28, 2011); Apple Inc., Annual Report (Form 10-K) (Oct. 27, 2010); Cisco Systems Inc., Annual Report (Form 10-K) (Sept. 21, 2010); Google Inc., Annual Report (Form 10-K) (Feb. 11, 2011); Intel Corp., Annual Report (Form 10-K) (Feb. 18, 2011); Kroger Co., Annual Report (Form 10-K) (Mar. 29, 2011); Microsoft Corp., Annual Report (Form 10-K) (Feb. 30, 2010). 
The implication of this discussion is that contemporary corporations provide limited capacity for implementing public policy. Judging from the employment practices of the most successful technology companies of the past quarter-century, there is little reason to expect that policies favoring corporate innovation will lead to a flood of new jobs-whatever their contribution to shareholder value.

\section{WHAT COMES NEXT?}

The history of the American corporation shows that there are critical unsettled periods when policy choices set a direction with longlasting implications. Public corporations were of relatively modest significance in the United States before the turn of the twentieth century. Nearly all were railroads or utilities; fewer than a dozen manufacturers listed their shares in 1890, and the largest manufacturer, Carnegie Steel, was a private partnership. Yet by 1905, thanks to a merger wave engineered by Wall Street that consolidated regional firms into national oligopolies in nearly every major industry, the familiar large-scale modern corporation was born. As William Roy shows, this outcome was far from inevitable in the United States, ${ }^{67}$ and the experience of the rest of the world showed the viability of functional alternatives, such as industrial districts. ${ }^{68}$ Moreover, a number of non-corporate alternatives arose to challenge the dominance of the public corporation, including mutuals, co-ops, and municipally owned firms. ${ }^{69}$

During the 1930s, the fraught relation between financial institutions and firms was set on a different course due to the Glass-Steagall Act, which ratified a strong boundary between finance and industry and created a free-standing constituency for financial markets in the form of the investment banking industry. Although Glass-Steagall was not the first time that policy intervened to keep American financial institutions weak, ${ }^{70}$ it was perhaps the most consequential. Yet Glass-Steagall was a choice, not an inevitability.

And as I have argued, policy decisions early in the Reagan years simultaneously created the conditions for the hostile takeover wave that unraveled the old corporate order and set in motion the shareholder value

67. See generally William G. Roy, Socializing Capital: The Rise of the Large INDUSTRIAL CORPORATION IN AMERICA (1997).

68. See generally Michael J. Piore \& Charles F. Sabel, The Second Industrial Divide: POSSIBILITIES FOR PROSPERITY (1984).

69. Marc Schneiberg, Toward an Organizationally Diverse American Capitalism? Cooperative, Mutual, and Local, State-Owned Enterprise, 34 SeAtTLE U. L. ReV. 1409 (2011).

70. $C f$. Mark J. Roe, Strong Mangers, Weak Owners: The Political Roots of AMERICAN CORPORATE FINANCE (1994). 
movement that replaced it. In retrospect, it is clear that 1982 was a turning point, but it could have been otherwise.

The United States now faces a similar critical period. Half of its public corporations have disappeared through multiple rounds of bubbles, scandals, and corporate failures. The first ten years of the twentyfirst century represented the single worst period of stock market performance in U.S. history. The S\&P 500 closed the first trading day of 2000 at $\$ 1,455.22$. On January 1,2010 , it stood at $\$ 1,115.10$, having declined by almost one-quarter over the decade. ${ }^{71}$ A generation that had hoped to retire on increased home values and an ever-rising stock market would require other plans. Not only is an economy organized around public corporations an increasingly risky place for workers, it is not a safe bet even for shareholders.

With the ready availability of the organizational technology for disaggregated production (as used by Apple, Nike, and Vizio), alternative means of large-scale financing (such as private equity), and a proliferation of alternative legal forms (such as LLCs and B Corporations), it is possible that we are reaching the twilight of the public corporation as the dominant form of business in the United States. Once again, what comes next is not foreordained. There is an opening for fruitful collaboration between social scientists and lawyers in their role as "transaction cost engineers" to help encourage new formats that better meet the needs of society, which have been left wanting since the collapse of the old corporate order. As this Article has suggested, the rise and intellectual dominance of the shareholder value concept of the corporation owed a great deal to the advent of the law and economics movement that connected lawyers and economists. Perhaps a similar movement could better connect lawyers with scholars of sociology and organizations of the sort convened by the Berle Symposium. The Berle and Means corporation served us well for many decades, until the shareholder value movement ultimately killed it off. It is time to contemplate what comes after its fitful disappearance.

71. $S \& P 500$ Index Historical Prices, YAHOO FINANCE, http://finance.yahoo.com/q/hp?s=^ $\mathrm{GSPC} \& \mathrm{a}=00 \& \mathrm{~b}=1 \& \mathrm{c}=2000 \& \mathrm{~d}=00 \& \mathrm{e}=1 \& \mathrm{f}=2010 \& \mathrm{~g}=\mathrm{w}$ (last visited Apr. 13, 2011). 